Deliberationes tudományos folyóirat 14. évfolyam 1. szám 2021/1, 149-159.

Kézirat beérkezése: 2021.04.17.

Kézirat befogadása: 2021.08.16.

DOI: 10.54230/Delib.2021.1.149
Deliberationes Scientific Journal Vol.14; Ed.No. 1/2021, pages:149-159

Paper submitted: 17th April 2021

Paper accepted: 16th August 2021

DOI: 10.54230/Delib.2021.1. 149

\title{
A BEREgSZÁSZI MALÁRIAÁLLOMÁS TEVÉKENYSÉGE A MÁSODIK VILÁGHÁBORÚ ÉVEIBEN
}

\author{
Orbán Melinda \\ II. Rákóczi Ferenc, Kárpátaljai Magyar Főiskola
}

\begin{abstract}
Absztrakt
A malária országon belüli elterjedtségével az 1930-as évektől kezdtek el foglalkozni Magyarországon. A betegség endémiás előfordulása különösen a délnyugati és az északkeleti területeket érintette. Emiatt több maláriaállomást hoztak létre, a második világháború évei alatt Kárpátalján két ilyen állomás működött Ungvár és Beregszász városokban. A feladatuk a kutatásra, a gyógyításra, a tanácsadásra, a védekezésre és a kísérleti munkára terjedt ki. A beregszászi állomás 1939-ben kezdte meg a tevékenységét, melynek során helyi sikereket értek el a szúnyoghálózás, a szúnyog tenyészőhelyek megszűntetése és a betegek gyógykezelése terén.
\end{abstract}

Kulcsszavak: endémia, maláriaállomás, Kárpátalja, Beregszász

\section{THE ACTIVITY OF THE MALARIA STATION AT BEREG- SZÁSZ DURING THE SECOND WORLD WAR}

\author{
Melinda Orbán
}

Ferenc Rákóczi II. Trancarpathian Hungarian College of Higher Education

\begin{abstract}
The spread of malaria within the country began to deal with in Hungary in the 1930s. The endemic incidence of the disease was particularly affected by the southwest and the northeastern areas. For this reason, several malaria stations were created during Second World War. These tasks included research, healing, counselling, defense and experimental work. In Transcarpathia malaria stations were established in the cities of Ungvár and Beregszász. The Beregszász Malaria Station started its activity in 1939. During this time, successes was achieved in mosquito screen, mosquito breeding sites and the treatment of patients were achieved.
\end{abstract}

Keywords: endemic, malaria station, Transcarpathia, Beregszász 
Az 1930-as évektől a Magyar Királyi Országos Közegészségügyi Intézet (OKI) intenzívebben kezdett foglalkozni a malária Magyarországon belüli elterjedtségével. Tanulmányozták a szúnyogfajtákat és a betegség előfordulási helyeit, illetve védekezési terveket dolgoztak ki. 1938-1940-ben az országhoz csatolt területek fertőzöttsége miatt emelkedett a malária előfordulási aránya (Johan, 1939, 1943; Kertai, 2005; Kerbolt, 1943). A bejelentések azonban csak a töredékét képezték a valóban előforduló esetek számának, tartósan és rendszeresen előfordult, különösen az ország délnyugati és északkeleti vármegyéiben. A Csallóköz, a Királyhelmectől keletre eső sáv, illetve Bereg és Ung vármegyék, a Tisza felső folyása voltak a legfertőzöttebb területek (Lőrincz et al., 1939; Makara et al., 1943; Lőrincz, 1982; Tomcsik, 1940, 1942, 1943; Hollaender, 1907). A mai Kárpátalja területén a huszti, a nagyszőlősi járások déli részei az érintett vidékekhez tartoztak, amely Beregszász környékét is magába foglalva felnyúlt északon Munkács és Ungvár felé. Az adatok arra utaltak, hogy az OKI hálózatát szükséges kibővíteni.

A betegséget kizárólag az Anopheles szúnyogfajok vagy más néven a maláriaszúnyogok közvetítik. A Kárpát-medencében a malária endémiás előfordulásának időszakában a megbetegedést elsősorban az Anopheles maculipennis fajcsoport tagjai terjesztették. A rovarok a tiszta, napos, növénnyel benőtt és táplálékban gazdag vízben tenyésznek. A legfontosabb tenyészőhely típusok a mocsarak, a rétek és a legelők voltak. A szúnyogirtás célpontja elsődlegesen a lárva volt. Mivel a fejlődéséhez vízre van szükség, így életterének a megszüntetésétől remélték a kiirtását (Kerbolt, 1943; Darányi, 1940; Melles, 2010; Birtalan, 1979; Kapronczay, 2008; Szergijev, 1949; Lörincz, 1982; Lepes, 1982). Azonban a lecsapolás nem minden esetben jelentett megfelelő megoldást, így eredményre vezethetett a víznívó emelése is. Mindemellett földmunkákkal is segítették az irtást, például a Beregszász környéki mocsaras gödröket betemették. Ezen kívül különféle vegyszereket használtak. A kontakt rovarölő szerek alkalmazásának lehetőségeit az 1940-es évektől kezdték tanulmányozni. Ennek keretében felhasználták nafta származékokat, a párisi zöldet ${ }^{1}$ (metilzöld), számottevően az '40-es évek közepétől a diklór-difenil-triklóretán ${ }^{2}$ vegyületet (DDT). A kártevő rovarok létszámcsökkentésének biológiai módszerei közül pedig a Gambusia affinis $^{3}$ halfaj említhető. A második világháború előtt a malária elleni küzdelem szim-

1 A párisi zöld kémiai megnevezése réz(II)-acetoarzenit. Az erősen toxikus szervetlen vegyületet rovarirtóként először Hollandiában alkalmazták 1921-ben. A vegyszernek számos más megnevezése ismert, mint például schweinfurti zöld, franciazöld stb. Báskay et al., 1998.

2 A DDT (diklór-difenil-triklóretán) rovarölő hatását Paul Hermann Müller (1899-1965) svájci kémikus bizonyította, aki 1948-ban orvostudományi Nobel-díjat kapott érte. A vegyszert már korában, 1874-ben előállította Othmar Zeidler (1850-1911). A második világháború ideje alatt és azt követően túlnyomóan az 1980-as évekig a különféle betegségeket terjesztő rovarok irtására és növényvédő szerként használták. Mivel jelentős pusztítást végzett a környezetben, ezért betiltották az alkalmazását. Nobelprize.org.

3 A Gambusia affinis más néven a szúnyogirtó fogasponty kistermetü hal, amely Észak-Amerika déli területeinek állóvizeiben honos faj. Nagy alkalmazkodó képessége miatt a víz összetételére és hőmérsékletére $\left(12-26^{\circ} \mathrm{C}\right)$ kevésbé igényes, így könnyen betelepíthető volt a számára idegen ökoszisz- 
bólumának számított, mivel egyik fö tápláléka a szúnyoglárva volt, ezért még a szúnyog kifejlődése előtt lehetőség nyílt korlátozni a szaporodásukat (Báskay et al., 1998; Makara et al., 1943; Lörincz et al., 1939; Erdős et al., 2008).

A maláriának nem csak egy kórokozója létezik, a váltóláz fogalma alatt valójában több betegség húzódik meg, melynek tünetei, következményei, terápiája és sajátosságai is különbözőek. Magyarországon a fertőzött szúnyogok évszakos előfordulása júliusszeptember hónapokra esett és jellemzően a Plasmodium vivax volt elterjedve (Lőrincz et al., 1939; Kerbolt, 1943; Darányi, 1940; Makara et al., 1943). Érdekes azonban, hogy a Plasmodium falciparum az északkeleti endémiás zónában előfordult, tehát érintette a mai Kárpátalja területét is. Két hullámban jelentkezett: a tavaszi a Palsmodium vivaxnak kedvezett, a nyár végi a Plasmodium falciparum megjelenését eredményezte (Lepes, 1982; Erdős et al., 2008).

A mai Kárpátalja területén a 20. század elején több betegség endémiás jelenlétéről beszélhetünk. A magasabb számban jelentkező megbetegedések közül a malária volt az egyik legelterjedtebb (Kapronczay, 2008; Kertai, 2005; Darányi, 1940; Tomcsik, 1940a; MNL BM K150. 4268. cs. XV. k. 9. t., 10. t.). A megjelenését általában három tényező befolyásolta a maláriás betegek jelenléte az adott területen, megfelelő tenyészöhelyek a szúnyogok számára és a malária-parazita fejlödésének körfolyamatát biztosító klimatikus feltételek. A betegség a fertőzést közvetítő szúnyogok élőhelyein volt elterjedt (Johan, 1943; Szergijev, 1949; Lepes, 1982). Napjainkban is ott magasabb a betegek száma, ahol a maláriaszúnyogoknak megfelelö életkörülmények biztosítottak a fejlődéshez és az életben maradáshoz. Ezek a trópusi éghajlatú, magas páratartalmú és pangó vizes területek.

Az OKI külső állomásainak hálózata a Magyarországhoz csatolt területek bekapcsolásával tovább bővült. A vármegyei maláriaállomások rendszerét megszüntették és 1940 januárjától már az újabban kiadott rendeletek, illetve megállapított müködési körzetek voltak érvényben. 1942-re összesen 7 állomás működött az ország területén. Kárpátalján Beregszász és Ungvár városokban hoztak létre maláriaállomást (Straub, 2001; Botlik, 2001; Kerbolt, 1943; MRT 1941; Bakács, 1959; Pápay, 1998; Kiss, 2004). Indokolt esetben a müködésüket egy másik állomásnak a területén is kifejthették. Az élén a belügyminiszter által, az OKI igazgatójának javaslatára kijelölt hatósági orvos állt, aki munkájáért külön tiszteletdíjban részesült. Ezen kívül a megbízott orvos és a szükséges személyzet teljesített még szolgálatot. Az orvos mellett rovartannal foglalkozó kutatót, azaz entomológust is alkalmazhattak. A segédszemélyzetet a vezetéssel megbízott hatósági orvos alkalmazta és állapíthatta meg a havi béreiket (Mihályi, 1963; Tomcsik, 1940; Zalamegyei Ujság, 1940; KTÁL, 42. f. 1. op. 388., 418., 420., 421., 423. od. zb.).

témákba. Valamennyi kontinens tropikus vagy mérsékelt övi, hőforrás táplálta vizébe betelepítették, mint természetes biológiai fegyvert. Báskay et al., 1998. 
A m. kir. belügyminiszter 1940. évi 1.000/1939. számú körrendelete hatályba lépésével az alábbi maláriaállomások kezdték meg a müködésüket. A beregszászi, melynek a működési körzete kiterjedt Bereg és Ugocsa közigazgatásilag egyelőre egyesített vármegyék területére kivéve a tiszaújlaki, a vásárosnaményi és a munkácsi járásokat. A csengeri, melynek a müködési területéhez tartozott Szatmár vármegye egész területe, illetve Bereg és Ugocsa k. e. e. vármegye tiszaújlaki járása. A mándoki, melynek a működési területe Szabolcs vármegye, Bereg és Ugocsa k. e. e. vármegyék vásárosnaményi járása, Ung vármegye ungi járása, a bodrogközi járás területének kivételével Zemplén vármegye területére terjedt ki. A nagykanizsai maláriaállomás müködési területe Somogy és Zala vármegyéket foglalta magába. Az ungvárinak a müködési területe kiterjedt a máramarosi, az ungi, a beregi közigazgatási kirendeltségek területére, illetve Bereg és Ugocsa k. e. e. vármegyék területének munkácsi járására, Ung vármegye nagykaposi és Zemplén vármegye bodrogközi járására (MRT 1940, 1941; Tomcsik, 1940).

A probléma jelentősen érintette Beregszász városát, ezt a földrajzi környezetének köszönhette. Az első Csehszlovák Köztársaság fennállásának időszaka alatt az 1930as években foglalkoztak a Vérke patak medermunkálataival, melynek szabályozásától remélték a mocsárlázas betegek számának csökkenését (Tomcsik, 1940). A város közegészségügyi viszonyainak a rendezése kapcsán az út menti árkok kimélyítése, a pocsolyák és gödrök betömése, valamint a szennyvízzel telt árkok befedése szerepelt a céljaik között. A környező mocsaras területeket többször petróleummal öntötték le. Mivel nagyobb számban előfordult a betegség, ezért a Prágai Egészségügyi Minisztérium 1937-től általános utasítást rendelt el a csatornák, illetve a mocsarak kiszárítására és fertőtlenítésére. A városban malária ambulancia működött, ami a kórházzal állt kapcsolatban, ahol vérvizsgálatokat és beteggyógykezelést végeztek (Prágai Magyar Hírlap, 1934, 1935, 1936, 1937, 1938).

A beregszászi maláriaállomás a tevékenységét már 1939 nyarán megkezdte. A munkálatokat kezdetben Aszalós János tiszti föorvos vezette, aki azonban fiatalon elhunyt. Ezt követően az állomás vezetőorvosa Szeles György, a városi orvos, entomológusa Mihályi Ferenc lett. Az elhelyezést a város biztosította, amely a központjában fekvő rendelö-laboratóriumból, váróteremből és egy kisebb raktárhelyiségből állt. Az első számú feladatok közé tartozott a váltólázas megbetegedések felszámolása a városban (Papp, 1998; Dely-Draskovits, 1997). A jelentés szerint az 1938. évi adatokat vetették össze az 1939. évi bejelentésekkel, így megállapították a legérintettebb területeket. Ennek alapján kitűnt, hogy a város északi peremterületei voltak a fertőzöttebbek. Ott helyezkedett el a lóversenytér, illetve a várost határoló mocsaras terület. Későbbi müködésük során negyedéves, féléves és éves jelentéseket állítottak össze, hogy nyomon követhessék a malária elleni tevékenységük hatékonyságát. A fiókállomások feladata a kutatásra, a gyógyításra, a tanácsadásra, a védekezésre és a kísérleti munkára terjedt ki. Ennek függvényében helyben végeztek vérvizsgálatokat, a visszaeső betegekkel konzultáltak és gyógyszert szolgáltattak ki díjtalanul. Leginkább a környező telepü- 
lésekre jutottak el ezek a gyógyszerek például Bene, Makkosjánosi, Csonkapapi. A gyógyszerek tabletta formában kerültek kiadásra, ezek között volt a kinin, a cortipan, az atebrin és a plasmochin. Hetente háromszor tartottak rendeléseket az akut esetek vizsgálatára. Szúnyogvizsgálatokra több száz szúnyogot gyüjtöttek be, majd kerültek boncolásra. Az első két évben szintén a várost közvetlenül övező területekről és a szomszédos kisebb településekről (Bulcsú, Beregardó). A szúnyog tenyészőhelyek felszámolására és a terület vizenyős részeinek feltöltésre javaslatokat tett az állomás a Magyar a Magyarért mozgalom helyi vezetőinek. Segítségükkel a Bercsényi utcai, a Keskeny utcai és a Rózsakerti pocsolyákat betemették, ezek mellett Bábotkai útjavításokat és a vizenyős területek feltöltését hajtották végre, mellyel a munkaképes segélyre szorulókat bízták meg (Tomcsik, 1940, 1941; Zalai Magyar Élet, 1941).

1940-ben a védekezést előkészítő helyzetfelmérés során megállapították, hogy a szúnyogtenyészet három fö területe a lóversenytér, a zsombékos és a Bábotka legelőre terjedt ki ismételten. Ideiglenes megoldásként párisi zöld szórást kezdtek meg. Az adatokat közölték a tiszti föorvossal, illetve kérték a lecsapolási és vízrendezési tervek elkészítését. Az ősz folyamán a munkácsi Kultúrmérnöki Hivatal megtartotta a helyszíni szemlét. Beregszász mellett Badaló, Bene, Beregardó, Bulcsú, Mezőgecse, Sárosoroszi, Tiszacsoma, Vári községben tisztogatási munkálatokat hajtottak végre közmunkásokkal (MRT 1941; KTÁL, 340. f. 1. op. 74. od. zb.; MNL BM K150. 4268. cs. XV. k. 10. t., K567. 1-8. cs. XVI. k.). A szúnyog tenyészőhelyek nagy részének feltérképezését az adott évben elvégezték. Az állomás entomológusa az ungvári malária tanfolyamon és a kórházi orvos társaság ülésén is tartott előadást. Nehezítette a munkát a laboráns három hónapos katonai szolgálatra való behívása. A laboratóriumi orvosi munkákat március 15-től augusztus 31-ig Szám László vette át. Mihályi Ferenc, az állomás entomológusa két év szolgálat után az áthelyezését kérte Budapestre. Az 1941-es tanévet az újpesti Állami Gimnázium tanáraként kezdte meg, valamint az OKI Parazitológiai Osztályán kutatóként dolgozott tovább (Tomcsik, 1941; DelyDraskovits, 1997; Bakács, 1959; Lőrincz et al., 1939; Kun, 1948).

1941-ben a csengeri és a mándoki állomások a munkájukat az év végére befejezték, helyettük a Délvidéken nyitottak újabbakat. A két megszünő állomás körzetét az ungvári, a szatmárnémeti és a beregszászi müködési körzetébe utalták. A szúnyogsürűségi vizsgálatok során tavasszal és ősszel a szúnyogszám az átlagosnál alacsonyabb, míg nyáron magasabb értéket mutatott. Az alábbi községekben befejezettnek tekintették a munkát az adott évre vonatkozóan: Asztély, Badaló, Balazsér, Bene, Beregardó, Bulcsú, Halábor, Kígyós, Macsola, Makkosjánosi, Mezőgecse, Nagybereg, Nagybégány, Nagymuzsaly, Sárosoroszi, Tiszacsoma, Vári és Zápszony. A tevékenységük során árkok, vályog- és anyaggödrök, kisebb mocsarak, folyó holtágak felszámolását sikerült befejezni. A Gambusia affinis halak alkalmasak voltak a kihelyezésre kisebb természetes vizekbe, esővízgyüjtőkbe, ahol a legtöbb szúnyoglárva fejlődött ki a tavaszi-nyári hónapokban. Betelepítésre került Beregardó községbe, azonban nem találták sikeresnek a kísérletet, mert a megfigyelések alatt nem 
csökkent a szúnyogok száma. Illetve a halak jelentős része elpusztult, annak ellenére, hogy a tartásának megfelelő eljárásokat alkalmazták. Az 1942-es év második felében az egészségházban müködött az állomás. Az állomás körzetében malária ambulanciát Tarpán és Vásárosnaményban állítottak fel. A két a mbulancia csak az év végén kezdte meg a müködését. Ezek a Zöldkeresztes Egészségvédelem keretében működtek, melyeket Tarpán Csanády György, Vásárosnaményban Kocsár Zoltán vezetett. Iskolás gyermekeknél vizsgálatokat az évben nem végeztek. A szúnyogszám-változást Beregszászban 3 helyen, illetve Bulcsú és Beregardó községekben figyelték meg. Tavasszal és ősszel alacsonyabb volt a számuk az addig megszokottnál (Tomcsik, 1942, 1943; Kapronczay, 2010).

A védekezés terén részt vett az állomás a Beregardó és a Makkosjánosi környékét érintő lecsapolás ügyében tartott helyszíni szemléken. A tervek elkészítésére ugyancsak a munkácsi Kultúrmérnöki Hivatalt kérték fel. A kutatómunka az évben csak a malária kezelésére alkalmazott gyógyszerek vizsgálatára szorítkozott, melynek során egy új összetételü cortipannal kezeltek betegeket. A gyógyszerrel kapcsolatban kiderült, hogy alkalmazható ugyan, de tapasztalhatóak voltak korai visszaesések. Az állomás vezetőorvosa Szeles György 1942. december 6-án elhunyt, így a megbízott laboratóriumi orvos Takács Ferenc kórházi föorvos vette át a helyét. Valamint továbbra is a megbízott orvosi és az entomológus állás betöltetlen maradt (Tomcsik, 1943; Boda, 1940; Orvosi Hetilap, 1943).

A felvilágosító tevékenységük során röplapokat osztottak ki nem csak a településeken, de a rendeléseken megjelent betegeknek is. Ma már hétköznapinak tűnő tanácsokat adtak a lakosságnak például használjanak szúnyoghálót az ablakokon, a házban a szoba ne legyen túl magas, fehérre legyen festve, nagy ablakok és ajtók legyenek rajta, illetve fontosnak tartották a szellőztetés megoldását (Kertai, 2005; Bakács, 1959). Ezen kívül az istállóknak a lakrésztől távolabbi elhelyezését tartották célszerünek és a fák, bokrok kiirtását közvetlen a bejárat elöl. Különféle praktikákat ajánlottak, mellyel elkerülhető a szúnyogok csípése, például szúnyogirtásra erős szagú olajokat (ricinusolajjal hígított citronella illóolajat), de ezek többnyire részmegoldásokat jelentettek (Rácz, 2010; Johan, 1939).

Az Európában is több országot érintő malária endémiás előfordulását csak a második világháború után sikerült tartósan rendezni. Az 1946-ban a World Health Organization (WHO) által jutatott nagy mennyiségü DDT-szórás hozta meg a kívánt eredményt. Kárpátalja területén a tereprendezések ellenére még mindig akadtak vizenyős, mocsaras területek a világháborút követően. A síkvidéki, illetve a Szernye mocsár körüli településeken előfordultak maláriás megbetegedések, amit az egészségügyi hatóságok az 1950-es évek végére tudtak felszámolni (Botlik, 2001; Erdős et al., 2008; Nemeséri, 1969). Magyarországon jelenleg is megtalálhatóak a kompetens vektorok, ilyenek a foltos-, a sziki- és a sárga maláriaszúnyog. Azonban a betegség újbóli megjelenéséhez és elterjedéséhez számos, egymással szorosan összefüggő feltételre lenne szükség (Tóth et al., 2004; Tóth, 1991; Báskay et al., 1998). 
A probléma napjainkban is rendkívül aktuális, mert a malária Afrika, Ázsia és DélAmerika egyes országaiban még mindig népbetegségnek számít. A parazita egysejtű által okozott betegség - a világon regisztrált kb. 400 millió esetből - évente átlagosan közel 1 millió halálos áldozatot követel. A Föld népességének közel a fele a fertőzés kialakulásának kockázatát növelő földrajzi környezetben él. (Siska et al., 2007; WHO WMR 2020).

Összességében a malária ellenes küzdelemhez hozzájárult az endémiás területeken létesített intézmények tevékenysége. Helyi sikereket értek el a szúnyoghálózás, a szúnyogtenyésző helyek megszüntetése és a betegek gyógykezelése terén. A heti rendelések alkalmával nem csak az akut esetek kezelésére nyílt lehetőség, de a lakosság figyelemfelhívására is. Az iskoláskorú gyermekek vizsgálata szintén jelentőségteljes volt, mert a korcsoport az egyik leginkább kitett a fertőzés veszélyének. A malária típusait figyelembe véve, a kor kellő orvostudományi ismereteivel rendelkezve különféle gyógyszerek kombinált alkalmazását javasolták az előforduló esetekben. Az állomáson a 20. század elején használt eljárásokat alkalmazták a szúnyogirtás területén is. Azonban akkor még nem számoltak az ökoszisztémára gyakorolt káros hatásukkal. A természetes úton való visszaszorítására a Gambusia affinis halfajt telepítették be az állomás működési területére is, - kevés gyakorlati haszonnal - az adott időszakban egyéb európai országokra is jellemző módon. A terepmunkálatokat a vályog és anyaggödrök, a mocsaras területek, a vizenyős legelők, a kisebb folyó holtágak feltöltése vagy lecsapolása jelentette. Hátráltatta a munkálatokat a katonai szolgálatra való behívás, valamint a hosszabb rövidebb ideig tartó laboráns és entomológus hiány.

Kapcsolattartó szerző:

Orbán Melinda

II. Rákóczi Ferenc

Kárpátaljai Magyar Föiskola 90200 Beregszász, Kárpátalja, Ukrajna

Kossuth tér 6.

melindaorban01@gmail.com
Corresponding author: Melinda Orbán

Ferenc Rákóczi II. Trancarpathian Hungarian College of Higher Education Kossuth square, 6. 90200 Beregszász, Transcarpathia, Ukraine melindaorban01@gmail.com 


\section{IRODALOMJEGYZÉK}

Arcanum Digitális Tudománytár. (1943). Vegyes hírek. Orvosi Hetilap. http://real-j. mtak.hu/11203/9/650.1943.07.03.pdf

Bakács, T. (1959). Az Országos Közegészségügyi Intézet müködése 1927-1957. Medicina Könyvkiadó.

Báskay, I., Pénzes, B., \& Repkényi, Z. (1998). Adatok a szúnyogirtó fogasponty (Gambusia affinis holbrooki Girard, 1859) táplálkozásához és szaporodásához hazai körülmények között. Állattani Közlemények, 83(1), 67-82.

Belügyminisztériumi Levéltár K150. Általános iratok. 4268. csomó. XV. kútfő. 9. tétel. Fertőtlenítő intézetek ügyei.

Belügyminisztériumi Levéltár K150. Általános iratok. 4268. csomó. XV. kútfő. 10. tétel. Fertőző betegségekkel szembeni védekezéssel kapcsolatos féregirtás szabályozása.

Belügyminisztériumi Levéltár K567. Orvosi Munkaerők Felhasználásának Kormánybiztosa. 1-8. csomó. XVI. kútfő. Orvosoknak honvédelmi munkára kötelezése, felmentése, elbocsátása. Zsidó orvosok gyógyászati eszközeinek felhasználása.

Birtalan, Gy. (1979). Adatok a két világháború között Magyarországon végzett szervezett egészségvédelmi munkáról, különös tekintettel az OKI tevékenységére. Orvostörténeti Közlemények, 87-88(1-2), 181-219.

Boda, F. (1940). A cortipan alkalmazása a csecsemő és gyermekgyógyászatban. Orvosi Hetilap, 84(32), 67-68.

Botlik, J. (2001). Volt egyszer egy Szernye mocsár II. Honismeret, 29(6), 76-85.

Darányi, Gy. (1940). Közegészségtan. Fertőző- és népbetegségek. (Járványtan). Magyar Orvosi Könyvkiadó Társulat Könyvtára.

Dely-Draskovits, Á. (1997). Dr. Mihályi Ferenc (1906-1997). Állattani Közlemények, 82(1), 5-11.

Erdős, Gy., \& Szlobodnyik, J. (2008). Csípőszúnyog vektorral terjedő fertőző megbetegedések Európában és Magyarországon III. Epinfo, 15(37), 433-438.

Hollaender, H. (1907). A malária elterjedése Magyarországon. M. Kir. Belügyminisztérium.

Hungaricana. (1934). A vízszabályozási munkálatok miatt négyezer maláriás megbetegedés történt egy év alatt Beregszászon. Prágai Magyar Hirlap. https://library. hungaricana.hu/hu/view/PragaiMagyarHirlap_1934_03/?query=beregsz\%C3\%A1 $\mathrm{sz} \% 20 \mathrm{mal} \% \mathrm{C} 3 \% \mathrm{~A} 1 \mathrm{ria} \% 20 \& \mathrm{pg}=300$ \&layout $=\mathrm{s}$

Hungaricana. (1935). Sándor Imre: Beszámoló Beregszásztól Nagyszőlősig. Prágai Magyar Hirlap. https://library.hungaricana.hu/hu/view/PragaiMagyarHirlap_1935 _01/?query=beregsz\%C3\%A1sz\%20mal\%C3\%A1 ria\%20\&pg=129\&layout=s

Hungaricana. (1936). Végre megindul a harc a Beregszászi malária leküzdésére. https:// library.hungaricana.hu/hu/view/PragaiMagyarHirlap_1936_05/?query=beregsz\%C 3\%A1sz\%20mal\%C3\%A1ria\%20\&pg=305\&layout=s 
Hungaricana. (1937). Beregszász erélyes akciója a malária ellen. Prágai Magyar Hirlap. https://library.hungaricana.hu/hu/view/PragaiMagyarHirlap_1937_07/?query=ber egsz\%C3\%A1sz\%20mal\%C3\%A1ria\%20\&pg=154\&layout=s

Hungaricana. (1937). Veszedelmesen terjed Kárpátalján a malária. Prágai Magyar Hirlap. https://library.hungaricana.hu/hu/view/PragaiMagyarHirlap_1937_07/?que ry=beregsz\%C3\%A1sz\%20mal\%C3\%A1 ria\%20\&pg=146\&layout=s

Hungaricana. (1938). Ezer malária megbetegedés egy év alatt Beregben! Prágai Magyar Hirlap. https://library.hungaricana.hu/hu/view/PragaiMagyarHirlap_1938_02/?que ry=beregsz $\%$ C3\%A1 sz\%20mal\%C3\%A1 ria\%20\&pg=129\&layout=s

Hungaricana. (1940). Hírek. Zalamegyei Ujság. https://library.hungaricana.hu/hu/view/ ZalamegyeiUjsag_1940_1/?query=beregsz\%C3\%A1sz\%20mal\%C3\%A1ria\%20 \&pg=70\&layout $=\mathrm{s}$

Hungaricana.(1941).2343szúnyogotboncoltakfelZalábanafertőzésifokmegállapítására. Zalai Magyar Élet. https://library.hungaricana.hu/hu/view/ZalaiMagyarElet_1941_ 2/?query=beregsz\%C3\%A1sz\%20mal\%C3\%A1 ria\%20\&pg=195\&layout=s

Johan, B. (1939). A racionális egészségpolitika alapelvei. Királyi Magyar Egyetemi Nyomda.

Johan, B. (1943). A magyar közegészségügy területi kérdései. Stádium Sajtóvállalat Rt.

Kapronczay, K. (Ed.). (2008). A magyarországi közegészségügy története 1770-1944. Jogalkotás, közegészségügyi intézmények, szakirodalom. Semmelweis Egyetem Közegészségtani Intézet, Semmelweis Orvostörténeti Múzeum, Könyvtár és Levéltár, Magyar Tudománytörténeti Intézet.

Kapronczay, K. (Ed.). (2010). A magyarországi közegészségügy szakterületeinek történetéböl 1876-1944. Magyar Tudománytörténeti Intézet, Semmelweis Orvostörténeti Múzeum, Könyvtár és Levéltár.

Kárpátaljai Területi Állami Levéltár (KTÁL, Державний архів Закарпатської області)

42. fond, 1. opisz, 388 od. zb. 7. 128.

42. fond, 1. opisz, 388. od. zb. 3. 8. 13.

42. fond, 1. opisz, 418. od. zb. 1.

42. fond, 1. opisz, 420. od. zb. 1-8.

42. fond, 1. opisz, 421. od. zb. 3. 5. 8.

42. fond, 1 opisz, 423. od. zb. 71.

340. fond, 1. opisz, 74. od. zb. 1.

Kerbolt, L. (1943). Fertözőbetegségek. A fertöző ragályos betegségek, járványok ismertetése a reájuk vonatkozó jogszabályokkal és Budapest székfóváros szabályrendeletének kivonta. Novák Rudolf és Társa.

Kertai, P. (2005). Járványok és járványügy a magyar történelemben II. A XX. század eseményei a századfordulótól a második világháború végéig. Magyar Epidemiológia, 2(1), 13-24.

Kiss, L. (2004). Egészség és politika - az egészségügyi prevenció Magyarországon a 20. század első felében. Korall, 17, 107-137. 
Kun, L. (1948). A volt ungvári OKI Állomás szovjet-rendszer szerinti újjászervezése. Népegészségügy, 29(23), 534-538.

Lepes, T. (1982). A malária elleni küzdelem múltja, jelene és jövője. Parasitologia Hungarica, 14, 5-11.

Lőrincz, F. (1982). A malária elleni küzdelem hazánkban az első világháború után visszaemlékezés. Orvostörténeti Közlemények, 97-99(1-3), 251-255.

Lörincz, F. (1982). Malária Magyarországon régen és ma. Parasitologia Hungarica, 14, $13-16$.

Lőrincz, F., \& Tomcsik J. (Eds.). (1939). A maláriáról. Magyar Orvosi Könyvkiadó Társulat Könyvtára.

Magyar Nemzeti Levéltár (MNL)

Magyarországi rendeletek tára 1940. (MRT) (1941). Stádium Sajtóvállalat Részvénytársaság Nyomdája.

Makara, Gy., \& Mihályi F. (1943). Rovarok és betegségek. Magyar Orvosi Könyvkiadó Társulat Könyvtára.

Melles, M. (2010). Az Országos Epidemiológiai Központ hagyományai az Országos Közegészségügyi Intézetben (1927-1997). DURSUSZ Kiadó-, Nyomda- és Reklámszolgáltató Bt.

Mihályi, F. (1963). A rovartani kutatások köz- és állategészségügyi jelentősége és eredményei hazánkban. Rovartani Közlemények, 16(2), 385-400.

Nemeséri, L. (1969). Dr. Lőrincz Ferenc professzor 70 éves. Parasitologia Hungarica, 2, 11-14.

Nobelprize.org. (2021). Paul Müller - Facts. https://www.nobelprize.org/nobel_prizes/ medicine/laureates/1948/muller-facts.html

Pápay, D. (1998). A „Johan Béla” Országos Közegészségügyi Intézet 70 éves müködése 1927-1997. Jubileumi évkönyv. OKI házi nyomdája.

Papp, L. (1998). In memoriam Dr. Ferenc Mihályi (1906-1997). Annales HistoricoNaturales Musei Nationalis Hungarici, 90, 5-16.

Rácz, J. (2010). Növények enciklopédiája. Az elnevezések eredete, a növények kultúrtörténete és élettani hatása. Tinta Könyvkiadó.

Siska, I., \& Jelenik, Zs. (2007). Utazók malária megbetegedésének kockázata. Epinfo, 14(48), 505-509. https://doi.org/10.1590/S0100-512X2007000200017

Straub, I. (2001). A közegészségügyi-járványügyi struktúra és a járványügyi helyzet változása Magyarországon Trianontól napjainkig. In Faragó, T., \& Öri, P. (Eds.), Történeti Demográfiai Évkönyv. (445-459.) Központi Statisztikai Hivatal.

Szergijev, P. G. (1949). A malária megelözése és gyógyítása. Uj Magyar Könyvkiadó.

Tomcsik, J. (1940). A M. Kir. Országos Közegészségügyi Intézet 1939. évben végzett munkájáról. „Pátria” Irodalmi Vállalat és Nyomdai Részvénytársaság.

Tomcsik, J. (1940a). A közegészségügy feladatai a Felvidéken és a Kárpátalján. Zöld Kereszt, 11(1), 4-7.

Tomcsik, J. (1941). Jelentés a M. Kir. Országos Közegészségügyi Intézet 1940. évben végzett munkájáról. „Pátria” Irodalmi Vállalat és Nyomdai Részvénytársaság. 
Tomcsik, J. (1942). Jelentés a M. Kir. Országos Közegészségügyi Intézet 1941 évben végzett munkájáról. „Pátria” Irodalmi Vállalat és Nyomdai Részvénytársaság.

Tomcsik, J. (1943). Jelentés a M. Kir. Országos Közegészségügyi Intézet 1942. évben végzett munkájáról. „Pátria” Irodalmi Vállalat és Nyomdai Részvénytársaság.

Tóth, S. (1991). Adatok a mocsári szúnyog, Mansonia (Coquillettidia) richiardii (Ficalbi, 1889) életmódjához és Magyarországi elterjedéséhez (Diptera: Culicidae). Bakonyi Természettudományi Múzeum Közleményei.

Tóth, S., \& Ábrahám L. (Eds.). (2004). Magyarország csípőszúnyog-faunája. Pethő és Társa Nyomdaipari Bt.

World Health Organization. (2020). World malaria report 2020. https://www.who.int/ publications/i/item/9789240015791 